\title{
Pre and Post-natal Nutrition of Ewes on the Performances of Native Bengal Ewes and Their Lambs
}

\author{
Sadek Ahmed ${ }^{1, ~ *, ~ M d . ~ R e z a u l ~ H a i ~ R a k i b ~}{ }^{1}$, Rahat Ara Karim ${ }^{1}$, Swapon Kumar Fouzder², \\ Nusrat Jahan $^{3}$, Nasrin Sultana ${ }^{1}$, Md. Ershaduzzaman ${ }^{1}$ \\ ${ }^{1}$ Goat and Sheep Production Research Division, Bangladesh Livestock Research Institute, Savar, Dhaka, Bangladesh \\ ${ }^{2}$ Department of Poultry Science, Patuakhali Science and Technology University, Patuakhali, Bangladesh \\ ${ }^{3}$ Animal Biotechnology Division, National Institute of Biotechnology, Savar, Dhaka, Bangladesh
}

\section{Email address:}

sadek.ahmed@blri.gov.bd (S. Ahmed)

${ }^{*}$ Corresponding author

\section{To cite this article:}

Sadek Ahmed, Md. Rezaul Hai Rakib, Rahat Ara Karim, Swapon Kumar Fouzder, Nusrat Jahan, Nasrin Sultana, Md. Ershaduzzaman. Pre and Post-natal Nutrition of Ewes on the Performances of Native Bengal Ewes and Their Lambs. Animal and Veterinary Sciences.

Vol. 5, No. 2, 2017, pp. 33-38. doi: 10.11648/j.avs.20170502.12

Received: February 12, 2017; Accepted: February 27, 2017; Published: March 18, 2017

\begin{abstract}
The aim of the study is to determine the effects of different plane of nutrition during late pregnancy to lactation on the performances of ewes and their offspring to weaning. About 36 native Bengal ewes of last 7 weeks gestation were randomly assigned to four different groups $\left(T_{0}, T_{1}, T_{2}, T_{3}\right)$. The $T_{0}, T_{1}, T_{2}$ and $T_{3}$ groups were supplemented a concentrate mixture at $0.0,1.0,1.5$ and $2.0 \%$ of their body weight, respectively. Chopped German grass (Echinochloa polystachya) was provided as basal forages to ewes and a creep mixture $(20 \mathrm{~g} / \mathrm{lamb} /$ day $)$ to the lambs from 2 weeks of age with a weakly increase of $10 \mathrm{~g} / \mathrm{lamb}$. The results shown that ewes dry matter intake $(\mathrm{p}<0.01)$, milk yield $(\mathrm{p}<0.05)$, days open $(\mathrm{p}<0.01)$, live weight gain before lambing $(\mathrm{p}<0.01)$ and at weaning $(\mathrm{p}<0.01)$ and weight recovery from late gestation to weaning $(\mathrm{p}<$ $0.05)$ improved with high plane of nutrition. Higher weight recovery found in $T_{2}$ group. Litter size had an effect on $(p<0.01)$ all weight traits of lambs and ewes milk yield. Sex of lamb also affects $(\mathrm{p}<0.05)$ the weaning weight and daily gain of lambs.
\end{abstract}

Keywords: Native Bengal Ewes, Lambs, Pre and Post-natal Nutrition

\section{Introduction}

Currently, the livestock sector in Bangladesh produced only $30.18 \%$ total requirement of meat and the per capita meat consumption is still very low (only $8.6 \mathrm{~kg}$ ) compared to developing countries $(42.1 \mathrm{~kg})$ and world $(32.2 \mathrm{~kg})$ [1]. To meet this huge gap, the meat production of the country must be increased in many folds with emphasizing different nonpopular species including sheep as a meat animal. Bangladesh has 3.16 million sheep which secure $3^{\text {rd }}$ position in number among the ruminant species of the country [2]. Though the number of animals is satisfactory but their performance is very poor. Nutrition is one of the major limiting factors in livestock production in Bangladesh and more than $90 \%$ of the feed consumed by the ruminants in our country are rice straw [3]. During pregnancy, nutrition is one of the very important factors that determine many productive and reproductive qualities after birth. In the late gestation, the last six to eight weeks of pregnancy, $80 \%$ of fetal growth occurs, leading to a significant increase in nutrient requirements of the ewe [4]. Inadequate feed intake during late gestation might lead to a reduction in birth weight (BW), mammary development and milk production [5, 6, 7 and 8]. Besides that, when multiple bearing ewes offered additional feed in late pregnancy, lamb mortality was reduced for single and twin lambs [9]. Research also revealed that body weight (BW) of lambs were higher when the ewes were fed higher levels of protein compared to the one that fed on low levels (14.9 vs. $11.3 \% \mathrm{CP}$ ) during late gestation and early lactation [10]. Therefore, it is necessary to find out a suitable nutrition level for native Bengal ewes during late pregnancy to lactation in view of effective lamb production in Bangladesh. Thus, the research was undertaken to know the effect of different level of nutrition during late pregnancy and 
lactation on the performances of native ewes and their lambs until weaning.

\section{Materials and Methods}

\subsection{Experimental Site and Duration}

The experiment was carried out at the Goat and Sheep Production Research Farm, Bangladesh Livestock Research Institute (BLRI), Savar, Dhaka-1341, Bangladesh during November 2014 to April 2015.

\subsection{Experimental Animals and Feeding Management}

A total of thirty-six native Bengal ewes between 2 to 5 parity were randomly allocated to four different treatment groups $\left(\mathrm{T}_{0}, \mathrm{~T}_{1}, \mathrm{~T}_{2}, \mathrm{~T}_{3}\right)$ at the stage of last 7 weeks pregnancy. Ewes were housed in individual cage and lambs remained with their dams until weaning except for the days of milk measurement. Ewes of all the treatment groups were supplied ad libitum German grass (Echinochloa polystachya) by chopping into the size of 1 to $1.5 \mathrm{inch}$. The ewes of $\mathrm{T}_{1}, \mathrm{~T}_{2}$ and $\mathrm{T}_{3}$ group were supplemented with a concentrate mixture (Crushed Maize 40\%, Soybean meal 26\%, Wheat bran 22\%, Rice polish $10 \%$, Salt $1 \%$, Vitamin-mineral premix $0.5 \%$ and DCP $0.5 \%$ ), at the rate of $1.0,1.5$ and $2.0 \%$ of their body weight, respectively and maintaining $\mathrm{T}_{0}$ as control. After parturition, a creep mixture (Crushed maize 68\%, Soybean meal 30\%, Vitamin-mineral premix $1 \%$ and Salt 1\%) was supplied to lambs at the age of 2 weeks @ 20g/lamb/day and a weekly increment of $10 \mathrm{~g} / \mathrm{lamb} /$ week was done. Beside this, a small amount of German grass was freely offered to the lambs in ad libitum basis from 04 weeks and onward. The required amount of grass and concentrates were divided into two equal parts and supplied twice daily (morning and evening).

\subsection{Parameter Studied}

Dry matter intake (DMI), weight changes during the period of pregnancy to lactation, milk yield (MY), rectal temperature, litter size and days open (DO) of ewes with birth weight (BW), sex, daily gain (DG) and weaning weight
(WW) of lambs were recorded. Weight of individual animal was measured at the onset of the trial and subsequently on weekly basis. Besides weekly weight, ewes were also weighted daily from 05 days before of their expected lambing date until lambing to identify the weight before lambing. The weights of the new natal lambs were taken immediate after parturition and before suckling milk and then weekly basis. Weight of the ewes was also taken at 06 hours after parturition i.e. after expelling placenta.

\subsection{Milk Yield Measurement}

Milk yield (MY) of ewes were estimated by using the Peart method [11] that is, weighing of the lambs before and after suckling and removal of residual milk by hand. Briefly, MY of ewes were measured over a total of $24 \mathrm{hrs}$ period and repeated over the lactation period. On the day of measurement lambs were removed at $20.00 \mathrm{hrs}$, and weighted $\left(\mathrm{M}_{1}\right)$ at $7.00 \mathrm{~h}$ next morning and allowed lambs for $45 \mathrm{~min}$ to obtain milk, weighted again $\left(\mathrm{M}_{2}\right)$ and the differences between $\mathrm{M}_{2}$ and $\mathrm{M}_{1}$ assume to be amount of milk consumed. There was no residual milk after suckling of lambs. The procedure repeated on the same day at $20.00 \mathrm{hrs}$ to measured MY for the other half of the day. The sums of two suckling yields measurements were assumed to be milk yield over $24 \mathrm{hr}$ periods. The single weekly estimate of MY was assumed to be representing the average MY for the week in which it was measured.

\subsection{Chemical Analysis of Experimental Diets}

Chemical compositions of the experimental diets are presented in the Table 1. Dry matter content of the feed was determined by drying the samples at $105^{\circ} \mathrm{C}$ overnight, while ash was measured by burning further at $600^{\circ} \mathrm{C}$ for 4 hours [12]. Dried samples were ground and passed through a $1 \mathrm{~mm}$ sieve before analysis. The CP content was determined using the Kjeldahl method [13]. The neutral detergent fibre (NDF) and acid detergent fibre (ADF) composition were analyzed using the method described by Goering and Van Soest [14].

Table 1. Chemical composition of the experimental diets.

\begin{tabular}{|c|c|c|c|c|c|c|c|c|}
\hline \multirow{2}{*}{ Diets } & \multirow{2}{*}{ DM (\% Fresh) } & \multicolumn{5}{|c|}{ Chemical composition (\%DM) } & \multirow{2}{*}{$\begin{array}{l}\text { Estimated ME } \\
(\mathrm{MJ} / \mathrm{kg} \text { DM) }\end{array}$} & \multirow{2}{*}{$\begin{array}{l}\text { Estimated TDN } \\
(\%)\end{array}$} \\
\hline & & Ash & OM & $\mathbf{C P}$ & ADF & NDF & & \\
\hline German grass & 15.85 & 11.70 & 88.30 & 10.61 & 46.31 & 74.67 & 6.41 & 43.27 \\
\hline Concentrate mixture (ewe) & 87.65 & 9.56 & 90.45 & 18.27 & 12.71 & 19.97 & 12.39 & 81.92 \\
\hline Creep mixture (lamb) & 88.29 & 6.18 & 93.82 & 17.86 & 11.56 & 15.88 & 12.56 & 83.24 \\
\hline
\end{tabular}

\subsection{Experimental Design and Statistical Analysis}

The experiment was arranged in a completely randomized design (CRD). The collected data were subjected to analysis of variance (ANOVA) using the general linear model (GLM) procedure of SAS 9.0 (2004). Significant differences among means were separated using the Duncan's multiple Range Test (DMRT).

\section{Results and Discussion}

\subsection{Performances of Ewes}

\subsubsection{Ewes Live Weight Changes}

The effect of different level of concentrate supplementation from last 06 weeks pregnancy to lactation stage on ewes live weight changes are presented in Table 2. Maternal nutrition during last stage of pregnancy plays an 
essential role in proper foetal and placental development that affects the health and productivity of the offspring. The results indicate that feeding concentrate had significant $(p<0.01)$ effect on LWG during last 06 weeks of pregnancy. Similarly, ewes live weight recovery from last 06 weeks pregnancy stage to lamb's weaning stage also significantly increased $(\mathrm{p}<0.05)$ in supplemented groups compare to control group $\left(\mathrm{T}_{0}\right)$. Higher body weight recovery rate was found in $\mathrm{T}_{2}$ group $(96.00 \%)$. On the other hand, the type of birth had only significant effect $(p<0.05)$ on weight gain of ewes during last 06 weeks of pregnancy but not in WW and WR after lambing compare to initial weight. On this regard, it is also found that during late pregnancy, ewes with high plane of feeding made significantly higher live weight gain than those on low plane $[7,8]$. The higher body weight recovery of supplemented groups during lactation would be expected to improve subsequent reproductive performances in ewes [11].

Table 2. Effect of different level of nutrition during late pregnancy to lactation and type of birth on weight (kg) changes of native Bengal ewes.

\begin{tabular}{|c|c|c|c|c|c|c|}
\hline Factors & $\begin{array}{l}\text { Initial weight } \\
(\mathrm{kg})\end{array}$ & $\begin{array}{l}\text { LW day before } \\
\text { lambing }(\mathrm{kg})\end{array}$ & $\begin{array}{l}\text { LW gain before } \\
\text { lambing (kg) }\end{array}$ & $\begin{array}{l}\text { LW after } \\
\text { lambing }(\mathrm{kg})\end{array}$ & $\begin{array}{l}\text { LW at weaning } \\
(\mathrm{kg})\end{array}$ & $\begin{array}{l}\text { WR (\%) from initial } \\
\text { weight to lambing }\end{array}$ \\
\hline $\mathrm{T}_{0}(8)$ & 25.84 & 27.42 & $1.58^{\mathrm{a}}$ & $23.23^{\mathrm{a}}$ & $20.95^{\mathrm{a}}$ & $81.70^{\mathrm{a}}$ \\
\hline $\mathrm{T}_{1}(9)$ & 26.42 & 30.81 & $4.39^{\mathrm{b}}$ & $26.81^{\mathrm{ab}}$ & $23.30^{\mathrm{ab}}$ & $88.55^{\mathrm{ab}}$ \\
\hline $\mathrm{T}_{2}(9)$ & 27.29 & 33.09 & $5.80^{\mathrm{b}}$ & $28.50^{\mathrm{b}}$ & $26.03^{b}$ & $96.00^{\mathrm{b}}$ \\
\hline $\mathrm{T}_{3}(7)$ & 21.80 & 27.84 & $6.04^{b}$ & $22.57^{\mathrm{a}}$ & $20.31^{\mathrm{a}}$ & $94.11^{\mathrm{b}}$ \\
\hline Overall mean & 25.54 & 29.98 & 4.44 & 25.50 & 22.84 & 90.10 \\
\hline SEM & 0.900 & 0.947 & 0.407 & 0.885 & 0.775 & 1.764 \\
\hline Sig. Level & NS & NS & $* *$ & $*$ & $*$ & $*$ \\
\hline Type of Birth & NS & NS & $*$ & NS & NS & NS \\
\hline Single (17) & 25.74 & 29.24 & $3.50^{\mathrm{a}}$ & 25.55 & 22.94 & 89.98 \\
\hline Twin (15) & 25.41 & 30.68 & $5.27^{\mathrm{a}}$ & 25.48 & 22.80 & 90.20 \\
\hline Triplet (1) & 23.90 & 32.00 & $8.10^{\mathrm{b}}$ & 25.00 & 21.70 & 90.79 \\
\hline Overall mean & 25.54 & 29.98 & 4.44 & 25.50 & 22.84 & 90.10 \\
\hline SEM & 0.900 & 0.947 & 0.407 & 0.885 & 0.775 & 1.764 \\
\hline
\end{tabular}

$\mathrm{NS}=$ Non significant; ${ }^{*} \mathrm{P}<0.05 ; * * \mathrm{P}<0.01 ;{ }^{\text {ab }}$ values within the same column with different superscripts differ significantly; LW= live weight; $\mathrm{T}_{\mathrm{o}}=$ no concentrate supplementation, $\mathrm{T}_{1}=$ Supplementation of concentrate at $1 \%$ of $\mathrm{LW}, \mathrm{T}_{2}=$ Supplementation of concentrate at $1.5 \%$ of $\mathrm{LW}$; $\mathrm{T}_{3}=\mathrm{Supplementation}$ of concentrate at $2 \%$ of $\mathrm{LW}$.

\subsubsection{Ewes Feed Intake}

The effects of different amount of concentrate offered during pre and post-natal period on DM intake of native ewes are shown in Table 3 . There was a significant $(\mathrm{p}<0.01)$ effect on the overall DM intake of ewes (DMI during pregnancy + lactation stage) compare to control group $\left(\mathrm{T}_{0}\right)$. Although DM intake among the groups $T_{1}, T_{2}$ and $T_{3}$ were not differ significantly. Likewise, DM intake during pregnancy and lactation stage also differ significantly $(\mathrm{p}<0.01)$ among the different treatment groups compare to control group $\left(\mathrm{T}_{0}\right)$. Ewes DMI from late pregnancy to lactation on their per cent body weight ware $3.05,3.79,3.38$ and $4.06 \%$ for $\mathrm{T}_{0}, \mathrm{~T}_{1}, \mathrm{~T}_{2}$, $\mathrm{T}_{3}$, respectively and also differ significantly $(\mathrm{P}<0.01)$ among the groups. Other research also found a non-significant effect on total DM intake by level of concentrate from 110 days pregnancy to lambing when fed two types of hays (lucern and pasture) as basal feed [15]. They also observed intake decreased with increasing level of concentrates.

Table 3. Effect of different level of nutrition during late pregnancy to lactation on the performances of native Bengal ewes.

\begin{tabular}{|c|c|c|c|c|c|c|c|}
\hline Parameters & $\mathbf{T}_{\mathbf{0}}$ & $\mathbf{T}_{1}$ & $\mathbf{T}_{2}$ & $\mathbf{T}_{3}$ & Overall mean & SEM & Lev. Sig. \\
\hline DMI of ewes $(\mathrm{kg})$ & $0.66^{\mathrm{a}}$ & $0.94^{\mathrm{b}}$ & $0.93^{\mathrm{b}}$ & $0.89^{\mathrm{b}}$ & 0.86 & 0.025 & $* *$ \\
\hline DMI during pregnancy (kg/day) & $0.51^{\mathrm{a}}$ & $0.94^{\mathrm{b}}$ & $0.86^{\mathrm{b}}$ & $0.90^{\mathrm{b}}$ & 0.80 & 0.035 & $* *$ \\
\hline DMI during lactation (kg/day) & $0.74^{\mathrm{a}}$ & $0.95^{\mathrm{b}}$ & $0.96^{\mathrm{b}}$ & $0.88^{\mathrm{b}}$ & 0.89 & 0.023 & $* *$ \\
\hline DMI on $\%$ LW of ewes during pregnancy & $2.00^{\mathrm{a}}$ & $3.36^{\mathrm{c}}$ & $2.87^{\mathrm{b}}$ & $3.64^{\mathrm{c}}$ & 2.96 & 0.129 & $* *$ \\
\hline DMI on $\%$ LW of ewes during lactation & $3.60^{\mathrm{a}}$ & $4.03^{\mathrm{ab}}$ & $3.66^{\mathrm{a}}$ & $4.31^{\mathrm{b}}$ & 3.88 & 0.092 & * \\
\hline Litter Size (no.) & 1.38 & 1.44 & 1.44 & 1.86 & 1.52 & 0.098 & NS \\
\hline Days Open (day) & $79.75^{\mathrm{b}}$ & $55.67^{\mathrm{a}}$ & $54.78^{\mathrm{a}}$ & $50.71^{\mathrm{a}}$ & 60.21 & 3.070 & $* *$ \\
\hline
\end{tabular}

$\mathrm{NS}=$ Non significant, $* \mathrm{P}<0.05, * * \mathrm{P}<0.01$, abc values within the same raw with different superscripts differ significantly. DMI $=$ Dry matter intake; To= no concentrate supplementation, $\mathrm{T} 1=$ Supplementation of concentrate at $1 \%$ of LW, T2 $=$ Supplementation of concentrate at $1.5 \%$ of LW; T3= Supplementation of concentrate at $2 \%$ of LW.

Since $80 \%$ of the foetal growth takes place in the last trimester of the pregnancy [4], nutritional requirements of the ewe increase to a great extent during this period. During the last six weeks of pregnancy energy requirements of twin bearing ewe are raised by more than $80 \%$ and protein requirements by $100 \%$ [16]. At the same time, pregnancy can reduce eating capacity but increase passage rate through the digestive tract [17]. Those combined changes in late pregnancy make it difficult to fill energy requirements of the pregnant and lactating ewe without using significant amounts of concentrates along with high quality roughage [18]. However, during the last 2 weeks of pregnancy, particularly 
in twin- or triple-bearing ewes; voluntary feed intake declines [19] although the demand for nutrients are higher at that stage. [20]. The above discussions suggest a concentrate supplementation along with green grass to meet increasing nutrient requirement during late pregnancy to lactation in ewes. In this study, DMI of all treated groups $\left(T_{1}, T_{2}\right.$ and $\left.T_{3}\right)$ significantly increased $(\mathrm{p}<0.01)$ compare to control group $\left(\mathrm{T}_{0}\right)$ both pregnancy and lactation stage to maintain the nutrient requirements.

\subsubsection{Daily Milk Yield}

The daily MY (g) of different treatment group were resulted significant differences $(\mathrm{p}<0.05)$ compare to control group $\left(\mathrm{T}_{0}\right)$ (Table-3). Ewes with higher level of concentrate groups $\left(\mathrm{T}_{3}\right)$ produced more milk during entire lactation period compare to control group $\left(\mathrm{T}_{0}\right)$ but not differ among the different supplemented groups $\left(T_{1}, T_{2}\right.$ and $\left.T_{3}\right)$. The results showed that MY increased with increasing the level of concentrate supplement $[21,6]$. MY was affected by the nutritional plane of before and after lambing.

Type of birth i.e. litter size significantly $(\mathrm{p}<0.01)$ affected daily MY of ewes. Highest MY found in the triplet bearing ewes (915.35 g/days) followed by twin (514.87 g/day) and single birth ewes (399.34 g /day) (Table 5). More MY also found in ewes which give birth to twins and reared twins compare to single birth ewes [6]. This may be associated with the simulation effect on the secretion cell of the udder which resulted from more frequent suckling by the lamb [22] or may be due to the sample size and genetics because in our study we got only one triplet birth.

\subsubsection{Days Open}

Days open (DO) also decreased significantly $(\mathrm{p}<0.01)$ with increasing concentrate supplementation during last 6 weeks of pregnancy to lactation (Table-3). The results indicate that supplementation improves the reproductive efficiency of ewes to reduce lambing interval. The overall DO of this study was 60.21 days however a lower value (42.73 days) reported for native Bengal ewes by other authors [23]. This variation may be due to the differences of parity of ewes, lambing season, level of nutrition, litter size and lambs sex.

Table 4. Effect of different level of nutrition during late pregnancy to lactation on the performances of native Bengal lambs.

\begin{tabular}{|c|c|c|c|c|c|c|c|}
\hline Parameters & $\mathbf{T}_{0}$ & $\mathbf{T}_{1}$ & $\mathbf{T}_{2}$ & $\mathbf{T}_{3}$ & Overall mean & SEM & Lev. Sig. \\
\hline Birth weight (kg) & 1.92 & 2.13 & 2.31 & 1.70 & 2.04 & 0.091 & $\mathrm{NS}$ \\
\hline Birth weight of male $(\mathrm{kg})$ & 1.96 & 2.16 & 2.24 & 1.75 & 2.01 & 0.115 & NS \\
\hline Birth weight of female $(\mathrm{kg})$ & 1.68 & 2.01 & 2.29 & 1.62 & 1.91 & 0.109 & NS \\
\hline Weaning weight $(\mathrm{kg})$ & 8.96 & 9.31 & 12.31 & 9.44 & 10.07 & 0.536 & NS \\
\hline Weaning weight of male $(\mathrm{kg})$ & $8.77^{\mathrm{a}}$ & $10.91^{\mathrm{ab}}$ & $13.23^{\mathrm{b}}$ & $9.90^{\mathrm{a}}$ & 10.83 & 0.598 & $*$ \\
\hline Weaning weight of female $(\mathrm{kg})$ & 8.43 & 8.78 & 10.57 & 8.26 & 8.96 & 0.511 & NS \\
\hline Daily live weight gain $(\mathrm{g})$ & 78.22 & 79.75 & 111.20 & 86.04 & 89.29 & 5.303 & NS \\
\hline Daily live weight gain of female $(\mathrm{g})$ & 74.94 & 75.22 & 92.10 & 73.83 & 78.38 & 4.808 & NS \\
\hline
\end{tabular}

$\mathrm{NS}=$ Non significant, ${ }^{*} \mathrm{P}<0.05$, ${ }^{*} * \mathrm{P}<0.01,{ }^{\text {ab }}$ values within the same raw with different superscripts differ significantly; $\mathrm{T}_{\mathrm{o}}=$ no concentrate supplementation, $\mathrm{T}_{1}=$ Supplementation of concentrate at $1 \%$ of $\mathrm{LW}, \mathrm{T}_{2}=$ Supplementation of concentrate at $1.5 \%$ of $\mathrm{LW}$; $\mathrm{T}_{3}=$ Supplementation of concentrate at $2 \%$ of $\mathrm{LW}$.

\subsection{Performances of Lambs}

The highest BW and WW were observed in $\mathrm{T}_{2}$ supplemented group (Table 4). Similarly, the highest WW also observed in $T_{2}$ treatment group. The results showed a non-significant effect of pre-natal nutrition on post-natal weight traits of lambs. But, WW and DG of male lambs until weaning differ significantly among the treatment groups.
Nevertheless, BW, WW and DG not differ significantly among the treatment groups but numerically higher values for all these traits found in $\mathrm{T}_{2}$ treatment group that may affect lambs slaughter weight and profitability. In Hamandi ewes a non-significant effect also found on post-natal weight traits of lambs for different plane of nutrition in late pregnant ewes $[6]$.

Table 5. Effect of type of lamb birth and lamb's sex on the performances of native Bengal lambs and ewes providing different levels of nutrition in ewes during late pregnancy to lactation.

\begin{tabular}{|c|c|c|c|c|}
\hline Factors & Birth weight of lambs (Kg) & Weaning weight of Lambs (kg) & Daily weight gain of lambs (kg) & Daily milk yield of ewes (g) \\
\hline Litter size (no.) & $* *$ & $* *$ & $* *$ & $* *$ \\
\hline Single (17) & $2.36^{\mathrm{b}}$ & $11.75^{\mathrm{b}}$ & $104.38^{\mathrm{b}}$ & $399.34^{\mathrm{a}}$ \\
\hline Twin (15) & $1.69^{\mathrm{a}}$ & $8.28^{\mathrm{a}}$ & $73.16^{\mathrm{a}}$ & $514.87^{\mathrm{a}}$ \\
\hline Triplate (1) & $1.72^{\mathrm{a}}$ & $8.45^{\mathrm{a}}$ & $74.80^{\mathrm{a}}$ & $915.35^{\mathrm{b}}$ \\
\hline Overall mean & 2.04 & 10.07 & 89.29 & 467.49 \\
\hline SEM & 0.091 & 0.537 & 5.303 & 30.711 \\
\hline Male (21) & 2.01 & $10.83^{\mathrm{b}}$ & $98.02^{\mathrm{b}}$ & - \\
\hline Female(24) & 1.92 & $8.96^{\mathrm{a}}$ & $78.38^{\mathrm{a}}$ & - \\
\hline Overall mean & 1.96 & 9.83 & 87.54 & - \\
\hline SEM & 0.080 & 3.948 & 0.410 & - \\
\hline
\end{tabular}

$\mathrm{NS}=$ Non significant, $* \mathrm{P}<0.05, * * \mathrm{P}<0.01,{ }^{\text {abc }}$ values within the same column with different superscripts differ significantly. 
It has been generally shown that BW of lambs not only depends on the nutrition of ewes during late stage of pregnancy but also correlated with litter size and sex of lambs. Similarly, growth and WW also depends on ewes' MY. So, the results of this experiment also compared according to litter size and sex of lambs (Table 5). Though lambs BW, WW and DG not differ significantly among treatment groups (Table 4) but litter size (single, twin and triplet) has significant effects $(\mathrm{p}<0.01)$ on these weight traits (Table 5). Single lambs were significantly heavier for all weight traits. This could be due to the quantities of milk available for them. With increasing litter size MY also increases, may be due to the simulation effect on the milk secretary cells of the udder which resulted from more frequent suckling by the lambs [22]. This result agrees with the findings in Hamandi ewes [6].

Although, overall BW of male lambs higher than female lambs but not differ significantly whereas, DG and WW differ significantly $(p<0.05)$. Thus, the effects of ewe's nutrition during late stage of pregnancy to lactation on lamb's $\mathrm{BW}, \mathrm{WW}$ and DG and ewes MY were interact with type of birth and sex of lambs.

\section{Conclusions}

The pre and post-natal nutrition of significantly affect all the weight traits of ewes from late pregnancy to lactation. Litter size not affect any weight traits of ewes expect weight gain before lambing. The LWR significantly increases in $T_{2}$ treatment group. DM intake also significantly improved in treatment groups compare to control group. MY significantly increases with increasing level of nutrition. Although, the BW, WW and DG of lambs not differ significantly among the treatment groups but numerically higher values observed in $\mathrm{T}_{2}$ treatment group for all these traits that would be expected to improve subsequent weight at slaughter age and profitability. Thus, it can be concluded that ad libitum green grass and a concentrate mixture at $1.5 \%$ of their live weight containing $18 \% \mathrm{CP}$ and $12 \mathrm{MJ} \mathrm{ME} / \mathrm{kg} \mathrm{DM}$ would be a suitable feeding regime during last stage of pregnancy to lactation to obtain optimum production from native Bengal ewes and their lambs.

\section{References}

[1] K. S. Huque, Changes in and challenges of Bangladesh livestock. BLRI Newsletter 3. Dhaka, Bangladesh: Bangladesh Livestock Research Institute; 2012. pp.1.

[2] DLS. Department of Livestock Services, Ministry of Fisheries and Livestock. Government of the People's Republic of Bangladesh, Dhaka, Bangladesh. 2014.

[3] M. J. Khan, K. J. Peters and M. M. Uddin, Feeding strategy for improving dairy cattle productivity in small holder farm in Bangladesh. Bang. J. Anim. Sci. 2009, 38(1\&2): 67 - 85

[4] J. J. Robinson, K. D. Sinclair, R. D. Randel and A. R. Sykes,
Nutritional management of the female ruminant: mechanistic approaches and predictive models. In: Proceedings of the $5^{\text {th }}$ International Symposium on Nutrition of Herbivores. American Society of Animal Science, Savoy, Illinois. USA: ISNH; 1999.

[5] S. P. Ford, B. W. Hess, M. M. Schwope, M. J. Nijland, J. S. Gilbert, K. A. Vonnahme, W. J. Means, H. Han and P. W. Nathanielsz, Maternal under nutrition during early to midgestation in the ewe results in altered growth, adiposity and glucose tolerance in male offspring. J. Anim. Sci. 2007; 85: 1285-1294.

[6] K. O. Aziz and S. S. Al-Dabbagh, Effect of plane of nutrition during late pregnancy and early lactation on milk production and lambs growth of Hamadani ewes. Jordan J. Agr. Sci. 2008; 4 (2): 148-157.

[7] D. H. M. Hamada, G. A. R. Sameh, A. Y. H. Mohamed and A. K. A. Enas, Effect of Maternal Feeding in Late Pregnancy on Behaviour and Performance of Egyptian Goat and Sheep and Their Offspring. Global Veterinaria. 2013; 11 (2): 168-176.

[8] M. Abd-Allah, Effects of Parity and Nutrition plane during late pregnancy on metabolic responses, Colostrum production and lamb output of Rahmani ewes. Egypt. J. Anim. Prod. 2013; 50(3):132-142.

[9] G. H. Scales, R. N. Burton and R. A. Moss, Lamb mortality, birth weight and nutrition in late pregnancy. New Zeal. J. Agr. Res. 1986; 29: 75-82.

[10] P. G. Hatfield, G. D. Snowder, W. A. Head Jr, H. A. Glimp, R. H. Stobart and T. Besser, Production by ewes rearing single or twin lambs: Effects of dietary crude protein percentage and supplemental zinc methionine. J. Anim. Sci. 1995; 73: 12271238.

[11] J. N. Peart, Lactation of suckling ewes and does. In sheep and goat production. In: Coop IE editor. Amsterdam, Netherlands: Elsevier Scientific Publishing Company; 1982. pp. 119-134.

[12] N. Thiex, L. Novotny and A. Crawford, Determination of ash in animal feed: AOAC official method 942.05 revisited. J. AOAC Int. 2012; 95(5):1392-7.

[13] AOAC (Association of Official Agricultural Chemists). Official Methods of Analysis. $10^{\text {th }}$ edition. Washington D.C. 2003.

[14] H. K. Goering and P. J. Van Soest, Forage Fiber Analysis (apparatus, reagents, procedures and some applications). Agrie. Handbook. ARS, USDA, Washington, DC. 1970. pp. 379 .

[15] T. Castro, F. F. Bermúdez, C. Valdés, A. R. Mantecónb, T. Manso and I. Salzar, The voluntary intake and utilization of forage-concentrate diets by ewes in late pregnancy. J. Anim. Feed Sci. 1994; 3: 181-189.

[16] J. Sveinbjörnsson and B. L. Ólafsson, Orkuparfir sauðfjár og nautgripa í vexti með hliðsjón af mjólkurfóðureiningakerfi [Energy requirements of sheep and growing cattle with respect to milk feed unit system]. Ráðunautafundur 1999; 127-204.

[17] J. J. Gonzalez, J. J. Robinson and C. Fraser, The effect of physiological state on digestion in the ewe and its influence on the quantity of protein reaching the abomasum. Livest. Prod. Sci. 1985; 12: 59-68. 
[18] J. J. Robinson, Nutrition of the pregnant ewe. In: Haresign W editor. Sheep Production. London: Butterworths; 1983. pp. $111-131$.

[19] R. J. Orr and T. T. Treacher, The effect of concentrate level on intakes of hays by ewes in late pregnancy. Anim. Prod. 1984; 39: 89-98.

[20] A. W. Bell, Regulation of organic nutrient metabolism during transition from late pregnancy to early lactation. J. Anim. Sci. 1995; 73: 2804-2819.
[21] S. Al-dain, Z. Qusay, E. A. Al-Rawi and K. A. Ayoub, Effect of using different nutrition levels on feeding pregnant Awassi ewes as affected in lamb growth, milk production and chemical composition. Tikrit J. Agric. Sci. 2003; 3(7): 48-60.

[22] J. B. Owen, Sheep Production. Bailliere and Tindall, London. 1976.

[23] M. R. Hassan and M. A. I. Talukder, Comparative performance of different regional native sheep in Bangladesh. The Bangladesh Veterinarian 2011; 28(2): 85-94. 